With 3 plates

\title{
The Effect of Nickel on a Marine Bacterium, Arthrobacter marinus sp.nov.
}

\author{
By A. B. COBET, ${ }^{*}$ C. WIRSEN, JUN. AND G. E. JONES \\ Department of Microbiology, University of New Hampshire, \\ Durham, New Hampshire 03824, U.S.A.
}

(Accepted for publication 21 April 1970)

\section{SUMMAR Y}

An unbalanced growth situation, resulting in large, plasmolysed spheroplasts (megalomorphs) produced by the addition of nickel to the growth medium of a marine bacterium, Arthrobacter marinus sp.nov., is described. The effect of increasing nickel concentrations was gradual. Under the cultural conditions used, a slight effect was noted on size in $\mathrm{I} \times \mathrm{IO}^{-4} \mathrm{M}_{-} \mathrm{NiCl}_{2}$, but in $4 \times 10^{-4} \mathrm{M}-\mathrm{NiCl}_{2}$ the cells formed megalomorphs attaining a size of Io to I $5 \mu \mathrm{m}$. Cell division did not occur in $5 \times 10^{-4} \mathrm{M}$-nickel. The lag phase of the culture increased from about $3 \mathrm{~h}$. without added nickel to more than $70 \mathrm{~h}$. at $4 \times \mathrm{IO}^{-4} \mathrm{M}$-nickel. Concurrently, the maximum population decreased as the nickel concentration was increased. The classification of the marine bacterium is described and the organism is designated as A. marinus sp.nov.

\section{INTRODUCTION}

There are few criteria which distinguish marine from fresh-water bacteria. The ability of marine bacteria to survive and grow in the ocean is their most salient feature (Jones, I968). The presence of heavy metals in the oceans is one of the factors limiting the survival of terrestrial bacteria in the marine environment (Scarpino \& Pramer, 1962; Jones, 1964). In the course of a survey to compare marine and fresh-water bacteria for their tolerance to nickel ions, an unusual morphological response was noted in several of the marine micro-organisms (Wirsen, 1966). The most unusual of these organisms and its megalomorphic response to these metal ions is described in this paper.

\section{Organisms and growth media}

\section{METHODS}

Arthrobacter marinus sp.nov. was isolated from a littoral water sample at Woods Hole, Massachusetts. The unusual morphological response was observed initially in cultures grown on a modified marine medium, 22I6E, of Oppenheimer \& ZoBell (I952) with $\mathrm{I} \times \mathrm{IO}^{-3} \mathrm{M}^{-\mathrm{Ni}^{2+}}$ as $\mathrm{NiCl}_{2}$ (Wirsen, I966). Subsequent investigations were performed on a stock culture not previously grown in the presence of added nickel. Stock cultures were transferred every 6 weeks to fresh slants of marine agar 22I6 (Difco Laboratory, Detroit, Michigan, U.S.A.), incubated at ambient temperature (23 to $27^{\circ}$ ) for $24 \mathrm{~h}$. and stored at 4 to $6^{\circ}$. This organism has been deposited in the American Type Culture Collection as ATCC 25374.

* Present address: Naval Medical Research Unit No. I, University of California, Berkeley, California 94720 , U.S.A. 
The type species of the genus, Arthrobacter globiformis ATCC 80 Io, was obtained and the stock culture maintained as above on slants of trypticase soy agar (Baltimore Biological Laboratory (B.B.L.), Baltimore, Maryland, U.S.A.).

The basal medium used in demonstrating the megalomorphic response contained Bacto-peptone $0.5 \mathrm{~g}$.; Bacto-yeast extract $0.5 \mathrm{~g}$.; ferric ammonium citrate $0.01 \mathrm{~g}$.; $75 \%$ synthetic sea water (Lyman \& Fleming, I940), I000 $\mathrm{ml}$. The final $\mathrm{pH}$ was $7 \cdot 8$ to $8 \cdot 0$. A I.OM aqueous solution of reagent grade $\mathrm{NiCl}_{2}$ (Mallinckrodt Chemical Works, St Louis, Missouri, U.S.A.) was prepared and the desired dilution added to the basal medium prior to sterilization by autoclaving at $\mathrm{I} 2 \mathrm{I}^{\circ}$ for $\mathrm{I} 5 \mathrm{~min}$.

\section{Identification of organism}

Cultures of Arthrobacter marinus and A. globiformis were plated on their respective growth media, and four single colony isolates of $A$. marinus and two of the type species were isolated, transferred to agar slants and maintained for use in the subsequent identification procedures. Cultural characteristics were determined using the criteria in the Society for American Bacteriologist's Manual of Microbiological Methods (1957), Cowan \& Steel (1965) and Skerman (1967). Growth cycle pleomorphism was observed and photographed by phase contrast microscopy. Hucker's modification of the Gram stain and the malachite green spore stain were used. Flagella were demonstrated by electron microscopy after shadow casting with tungstic oxide.

Growth characteristics and colony morphology were determined by inoculation to: extract agar (B.B.L.), extract broth (B.B.L.), tryptose-glucose-extract agar (Difco) and potato-dextrose agar (B.B.L.), all prepared in $75 \%$ synthetic sea water, and marine agar prepared in distilled water. Trypticase soy agar-soil extract (TSA-soil extract) was prepared using trypticase soy agar (B.B.L.), with 50\% soil extract (Pringsheim, I964) and 50\% distilled water. Nicotine agar (Sguros, 1955) and thiotone broth (Blankenship \& Doetsch, I96r) were prepared both in $75 \%$ synthetic sea water and in distilled water.

All the following media were prepared in $75 \%$ synthetic sea water and after inoculation, incubated at 24 to $27^{\circ}$. Oxidative or fermentative capacity was determined by using Hugh \& Leifson medium (1953) containing glucose. The utilization of the carbohydrates, glucose, sucrose, galactose, lactose, mannitol, mannose, maltose, inositol, glycerol, ribose, xylose, sorbitol, arabinose, rhamnose, salicin and dextrin was determined by two methods: phenol red broth (Difco) with $0.5 \%$ carbohydrate, and secondly in a synthetic basal medium composed of $\mathrm{NH}_{4} \mathrm{NO}_{3}, 0 . \mathrm{I} \% ; \mathrm{K}_{2} \mathrm{HPO}_{4}$, $0.002 \%$; phenol red, $0.002 \%$; asparagine, $20 \mu \mathrm{g} . / \mathrm{ml}$. and supplemented with carbohydrate, $\mathrm{I} \cdot 0 \%$. Cellulose utilization was demonstrated by placing strips of Whatman no. 2 filter paper (W \& R Balston Ltd) in the above synthetic basal medium without the phenol red indicator. Simmon's citrate medium (B.B.L.) and Koser's citrate broth (Difco) were used to demonstrate citrate utilization. The medium of Dubos \& Miller (I937) prepared both in $75 \%$ synthetic sea water and in distilled water was used to determine the utilization of creatinine and creatine as sole source of nitrogen and/or carbon. For testing the utilization of creatinine and creatine as sole carbon source, $0.5 \%\left(\mathrm{NH}_{4}\right)_{2} \mathrm{SO}_{4}$ was added to the media. Growth in media containing $\mathrm{NH}_{4} \mathrm{Cl}$ or $\mathrm{KNO}_{3} \mathrm{O} \cdot \mathrm{I} \%$, glucose $\mathrm{I} \cdot 0 \%$ and $\mathrm{K}_{2} \mathrm{HPO}_{4} 0.005 \%$ was used to test for the utilization of ammonium and nitrate ions as sole source of nitrogen. The ability to utilize atmospheric nitrogen as sole source of nitrogen was determined in a medium composed of 
mannitol, I.5\%; $\mathrm{MgSO}_{4} .6 \mathrm{H}_{2} \mathrm{O}, 0.02 \% ; \mathrm{K}_{2} \mathrm{HPO}_{4}, 0.02 \% ; \mathrm{NaCl}, 0.0 \mathrm{I} \%$; $\mathrm{CaSO}_{4} \cdot 2 \mathrm{H}_{2} \mathrm{O}, 0.0 \mathrm{I} \% ; \mathrm{CaCO}_{3}, 0.5 \%$, and Noble agar (Difco), $\mathrm{I} \cdot 5 \%$ in distilled water.

Nitrate reduction was determined in trypticase soy broth (B.B.L.) containing $0.1 \%$ $\mathrm{KNO}_{3}$ using the Griess-Ilosvay reagent; indole production in trypticase soy broth using Kovac's reagent; $\mathrm{H}_{2} \mathrm{~S}$ production on lead acetate agar (Difco) slants and extract agar with $0.1 \%$ cysteine and $0.02 \% \mathrm{FeSO}_{4} \cdot 7 \mathrm{H}_{2} \mathrm{O}$; acetylmethylcarbinol production in MR-VP medium (B.B.L.) using Barritt's method (1936). Urease production was tested in Bacto-urea broth (Difco) prepared both in $75 \%$ synthetic sea water and in distilled water; catalase with $3 \% \mathrm{H}_{2} \mathrm{O}_{2}$ and oxidase by Kovac's oxidase reagent. Hydrolysis of gelatin was determined on extract agar with $0.4 \%$ gelatin (Difco) by flooding the plates with acid mercuric chloride solution and by liquifaction of stab cultures in extract broth containing $12 \%$ gelatin. Incubation was at $20^{\circ}$ and at $25^{\circ}$. Starch hydrolysis was determined on starch agar (Difco) by flooding plates with iodine solution.

The growth response to temperature was determined in a medium consisting of peptone, $0.05 \%$; yeast extract, $0.05 \% ; \mathrm{MgCl}_{2} .6 \mathrm{H}_{2} \mathrm{O}, 0.3 \% ; \mathrm{CaCO}_{3}, 0.06 \% ; \mathrm{KCl}$, $0.04 \%$; and $\mathrm{NaCl}, 7.02 \%$ in distilled water.

\section{Base composition of DNA}

Deoxyribonucleic acid (DNA) was isolated by the method of Marmur (I96I) and the guanosine + cytosine $(\mathrm{G}+\mathrm{C})$ molar concentration determined by the method of Wang \& Hashagen (1964). Fish sperm DNA (Sigma Chemical Co., St Louis, Missouri, U.S.A.) was used as control. The $5^{\prime}$-monophosphates of thymidine and the deoxy forms of guanosine, adenosine and cytodine were used in preparing the standards.

\section{RESULTS}

Characteristic proportion of the isolate, Arthrobacter marinus sp.nov.

A striking characteristic of the genus Arthrobacter is its extreme morphological variability during growth. This was characterized originally by Conn \& Dimmick (I947) as, 'Varied, with a tendency to go through a more or less definite cycle, the most characteristic features of which are Gram-negative rods in young cultures and Gram-positive coccoid forms (arthrospores) in old cultures.' Skerman (I967) definitely stated, 'Ultimately the rods transform completely to cocci,' and considered the transformation of the cocci through rods to cocci again as a prime feature of the genus.

The marine organism isolated by us exhibited this cyclic growth pattern and therefore met the principal requirement for the definition of the genus. In the stationary phase the bacteria were single and coccoid in shape, measuring 0.6 to $0.8 \mu \mathrm{m} . \times \mathrm{I} \cdot 0 \mu \mathrm{m}$. (Pl. I, fig. I). When the coccoid organisms were inoculated onto marine agar they elongated into large rods about $\mathrm{I} \cdot 2$ to $\mathrm{I} \cdot 5 \mu \mathrm{m} . \times 2 \cdot 0$ to $4 \cdot 0 \mu \mathrm{m}$. during the logarithmic phase of growth (Pl. I, fig. 2). As the culture reached the early stationary phase the cells gradually became smaller, ranging from about $\mathrm{I} \cdot 0$ to $\mathrm{I} \cdot 5 \mu \mathrm{m} . \times 2 \cdot 0 \mu \mathrm{m}$. With further incubation the sizeand shape of the cell completed the cycle, becoming coccoid in about 5 days (P1. I, fig. 3). The rods were often slightly bent and appeared singly, more often in pairs, and occasionally in short chains of three to four cells. The daughter cells of dividing rods were often in $\mathrm{V}$ formation, a characteristic commonly seen in coryneform bacteria (Starr \& Kuhn, 1962). 
Motility, observed in hanging drop preparations, was most evident in cells from the logarithmic (rod-shaped) phase of growth. Electron photomicrographs showed the presence of a single, subpolar flagellum consisting of two thin very long strands (Pl. I, fig. 4,5 ). The position of the flagellum is similar to that found in the "degenerate peritrichous' group described by Conn, Wolfe \& Ford (I940).

The Gram reaction varied with growth conditions. In very young cultures from marine agar slants, the rods were Gram-negative. In older cultures the cocci appeared to be Gram-positive, but on closer examination many of the cells clearly have a Gramnegative cytoplasm with large positively-stained granules. These granules are evident in the phase contrast photomicrographs (Pl. I, fig. 3) and appear to be similar to those observed by Jensen (I960). Two week old cultures from TSA-soil extract and marine agar slants stained with malachite green showed no signs of spores.

\section{Cultural characteristics}

Agar slant: growth was luxuriant, filiform, glistening, butyrous (extract, potatodextrose agar) becoming viscid on ageing (marine, TSA-soil extract agar) or viscid (tryptose-glucose extract agar), ivory or cream, opaque, marine agar) or translucent (potato-dextrose agar).

Agar plate: colonies are circular, 2.0 to $5.0 \mathrm{~mm}$. in diameter depending on the medium, convex, entire margin, smooth with the colony consistency and colour as above.

Broth: slight surface ring, dense uniform turbidity with a viscid sediment.

No pigment was formed on the synthetic sea water-nicotine agar. Cells of normal morphology occurred in the thiotone broth prepared with synthetic sea water. The organism failed to grow in both media prepared with distilled water.

The following tests were negative: hydrolysis of gelatin and starch, nitrate reduction, indole, acetylmethylcarbinol and urease production and oxidase. Positive results were obtained in $\mathrm{H}_{2} \mathrm{~S}$ production, citrate utilization and catalase. The culture was weakly oxidative in the Hugh \& Leifson medium.

Good growth occurred in litmus milk with reduction of the litmus. The milk slowly cleared without coagulation, clearing being complete in three weeks with the production of an abundant viscid growth.

No growth occurred in creatinine, creatine, cellulose or nitrogen-free media, indicating that the organism could neither utilize creatinine, creatine or cellulose as sole source of carbon, nor utilize creatinine, creatine or atmospheric nitrogen as sole source of nitrogen. Growth occurred in the inorganic nitrogen media demonstrating the ability to utilize nitrate and ammonium ions as a nitrogen source and that growth factors are not required by the organism.

The growth temperature range was from $6^{\circ}$ (the lowest temperature used) to $40^{\circ}$. Most rapid growth occurred at $40^{\circ}$, with a maximum population at $25^{\circ}$. No growth was obtained at $42^{\circ}$.

The $\mathrm{G}+\mathrm{C}$ molar composition of Arthrobacter marinus, A. globiformis, fish sperm and calf thymus DNA, using the indirect method of Wang \& Hashagen (I964) are presented in Table $\mathrm{I}$. The $\mathrm{G}+\mathrm{C}$ value of 63.3 for $A$. marinus is in accord with the range of values found for the type species of $A$. globiformis.

In phenol red broth base with $0.5 \%$ carbohydrate the culture produced acid but no gas from glucose, galactose and sucrose, but weak acid from mannitol. An alkaline 
reaction occurred in arabinose, xylose, glycerol, lactose, and dextrin. No $\mathrm{pH}$ change occurred in the other carbohydrates. In the synthetic basal medium with I \% carbohydrate, acid but no gas was produced in glucose, galactose, sucrose, glycerol, maltose, mannose, mannitol, inositol and ribose; there was slow acid production in lactose. No $\mathrm{pH}$ change occurred in the other carbohydrates.

Table I. Guanosine plus cytosine $(G+C)$ percent molarity of Arthrobacter marinus DNA using the method of Wang \& Hashagen (I964)

\begin{tabular}{lcc}
\multicolumn{1}{c}{ Sample } & $\begin{array}{c}\text { G+C } \\
(\% \mathrm{M})\end{array}$ & $\begin{array}{c}\text { Previously } \\
\text { published } \\
\text { data }\end{array}$ \\
Arthrobacter marinus & $63 \cdot 3$ & - \\
Arthrobacter globiformis & $64 \cdot 3$ & 62 to $64(\mathrm{I})$ \\
Calf thymus DNA & $40 \cdot 7$ & $40(2)$ \\
Fish sperm DNA & $4 \mathrm{I} \cdot 9$ & -
\end{tabular}

References: (1) Marmur, Falkow \& Mandel, 1963; (2) Schildkraut, Marmur \& Doty, 1962.

The use of phenol broth medium for detecting acid production from carbohydrates was unsatisfactory as the alkaline reaction, presumably from the breakdown of peptone, masked the acid produced from the carbohydrate. After $48 \mathrm{~h}$. incubation, at ambient temperature $\left(24\right.$ to $27^{\circ}$ ) the phenol broth medium showed acid reactions in three of the 16 carbohydrates tested, whereas 10 acid reactions occurred in the synthetic basal medium with Arthrobacter marinus. The type species, A. globiformis, produced acid reactions from I4 carbohydrates in the synthetic basal medium and none in the phenol broth medium during the same time interval. At the end of I week, the number of positive reactions in the synthetic basal medium increased by only one carbohydrate for each organism: lactose for A. marinus and ribose for A. globiformis. The synthetic medium, once acid, did not revert to a neutral or alkaline reaction as had occurred with the peptone containing medium. Conn \& Dimmick (1948) found the same problem with the peptone medium and used a synthetic medium to characterise the species $A$. simplex.

Arthrobacter marinus has a definite inorganic requirement which is easily satisfied by the addition of sea water. ZoBell \& Upham (1944) studied several biochemical reactions of marine bacteria in both fresh- and sea-water media and noted quantitative but no marked qualitative differences in the results. Sea water must be used in the media.

\section{Growth response of Arthrobacter marinus to nickel concentrations}

The growth response of Arthrobacter marinus to nickel was determined by the addition of increasing concentrations of $\mathrm{NiCl}_{2}\left(\mathrm{I} \times \mathrm{IO}^{-4}\right.$ to $\left.5 \times \mathrm{IO}^{-4} \mathrm{M}\right)$ to the basal medium. This resulted in an extension of the lag phase from about $3 \mathrm{~h}$. in the unsupplemented control to over $70 \mathrm{~h}$. in the presence of $4 \times 10^{-4} \mathrm{M}$-nickel (Fig. I). At a concentration of $5 \times 10^{-4} \mathrm{M}$-nickel the culture did not grow during a period of $144 \mathrm{~h}$. The slope of the line during the logarithmic phase of growth decreased with each increase in the nickel concentration, resulting in an increased time required to reach maximum extinction (growth) at the higher nickel concentrations. Since the light transmittance depends on the size and shape of the particles, as well as on their 
numbers, the values are relative and are presented to show the initiation of growth, general shape of the curve, and the time to reach maximum extinction at each nickel concentration. The occurrence of the maximum extinction coincided with the maximum population value of the culture. The populations normally associated with the maximum extinction are presented in Table 2.

The formation of the megalomorphic cells was a graded response and dependent upon the concentration of nickel, being most evident at $4 \times 1 \mathrm{IO}^{-4} \mathrm{M}$-nickel in the basal medium. Plate 2 presents photomicrographs comparing the maximum size of megalomorphs from cultures with the various nickel concentrations with bacteria from

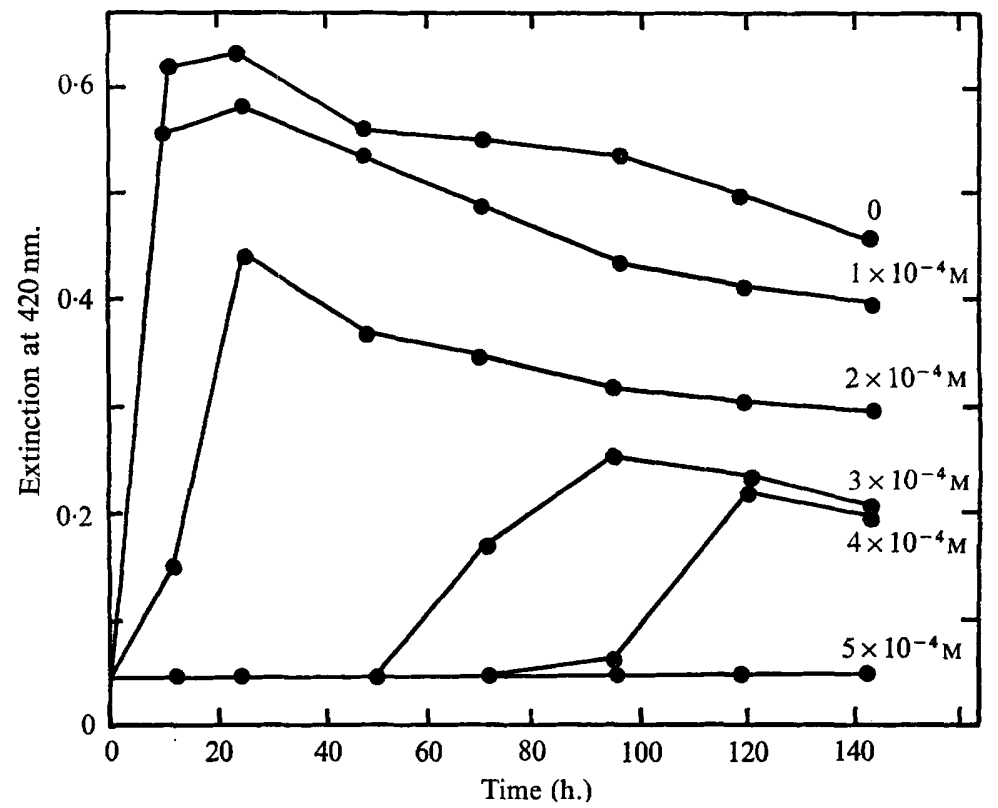

Fig. I. Growth response of Arthrobacter marinus to nickel. Increasing molar concentrations of nickel were added to the basal medium inoculated with an $18 \mathrm{~h}$. culture and shaken at $300 \mathrm{rev} . / \mathrm{min}$. at $25^{\circ}$. Samples taken at intervals and extinction read in a Bausch and Lomb Spectrophotometer at $420 \mathrm{~nm}$.

Table 2. Plate count populations and the size of Arthrobacter marinus cells in various concentrations of nickel at $25^{\circ}$

$\begin{aligned} & \text { Concentration } \\ & \text { of } \mathrm{Ni}\end{aligned}$
$(\mathrm{M})$
No addition
$\mathrm{I} \times 10^{-4}$
$2 \times 10^{-4}$
$3 \times 10^{-4}$
$4 \times 10^{-4}$

Plate count (cells $/ \mathrm{ml}$.)

5 to $8 \times 10^{8}$

3 to $6 \times 10^{8}$

3 to $6 \times 10^{7}$

3 to $5 \times 10^{6}$

4 to $7 \times 10^{5}$

$$
\begin{gathered}
\text { Maximum average } \\
\text { size } \\
(\mu \mathrm{m} .) \\
2 \times 4 \\
2 \times 4 \\
2 \text { to } 3 \times 4 \text { to } 6 \\
7 \text { to } 10 \text { in diam. } \\
\text { I0 to } 5 \text { in diam. }
\end{gathered}
$$

the control culture. The most dramatic change in morphology occurred between $2 \times 10^{-4}$ and $3 \times 10^{-4} \mathrm{M}$-nickel concentrations. Considerable vacuolation of the megalomorphs developed which increased with time and nickel concentration. The shape of the cells were generally round to oval, with cytoplasm pushed over to one side of the 
cell in a crescent shape. As the cell became older, the cytoplasm became more vacuolated and the shape more irregular. In the stationary phase culture, the cells became smaller but retained the vacuoles and crescent-shaped cytoplasm.

When cells were inoculated into the basal medium containing $4 \times 10^{-4} \mathrm{M}$-nickel and samples were removed periodically for observation by phase contrast microscopy, the majority $(>95 \%$ ) were observed to have undergone transformation to megalomorphs. Plate 3 shows the course of this enlargement in comparison with the original inoculum (Pl. 3, fig. I2). After I.5 h. incubation, the cells were somewhat larger and more oval-shaped than the control logarithmic phase rod. In some instances, a small vacuole was formed at the end of the cell. An occasional cell was seen to bulge in the middle as if the newly formed cell wall had weakened and was unable to retain the rod shape. The cells at this stage have an even phase density (Pl. 3, fig. I3). After $2.5 \mathrm{~h}$. incubation, the nickel-treated cells became larger with a wide variation in phase density within the cell (Pl. 3, fig. I4). A tremendous change in size occurred during the subsequent $2 \mathrm{~h}$. incubation period. During this time the cells were still somewhat oval, over half the volume appearing as vacuoles, and the size increased by about 30 volumes (Pl. 3, fig. I5) in relation to the control. After $6.5 \mathrm{~h}$. incubation, the cells had increased to 70 volumes, and became multivacuolated (Pl. 3, fig. I6). At $10 \mathrm{~h}$. incubation the cells were 3.5 times larger than at $6.5 \mathrm{~h}$., multivacuolated and more irregular in shape (Pl. 3, fig. I7). These cells after $10 \mathrm{~h}$. incubation in $4 \times 10^{-4} \mathrm{M}$-nickel, were about 250 volumes larger than the untreated normal size rod with approximately $40 \%$ of the cell volume being crescent-shaped cytoplasm against the cell wall and $60 \%$ as a vacuole. The megalomorphic cells formed after $4.5 \mathrm{~h}$. incubation were osmotically sensitive when placed in distilled water: the protoplasts burst, leaving the cell walls intact and resembling hollow spheres.

The megalomorphic cells, when returned to the basal medium without nickel, resumed division and rapidly produced normal size rods.

\section{DISCUSSION}

The morphological, cultural, physiological and $\mathrm{G}+\mathrm{C}$ molar composition of this recently isolated marine micro-organism indicates a close relationship to the genus Arthrobacter. The isolate also exhibits properties that clearly distinguish it from species of the genus previously described by Lochhead (I957). Its characteristics also differ significantly from the published descriptions of $A$. crystallopoietes (Ensign \& Rittenberg, I963), A. duodecadis, A. flavescens (Lochhead, I958), A. atrocyaneus (Kuhn \& Starr, 1960), A. polychromogenes (Schippers-Lammertse, Muijsers \& Klatser-Oedekerk, 1963), A. viscosus (Gasdorf, Benedict, Cadmus, Anderson \& Jackson, 1965), and $A$. ramosus (Jensen, 1960). The genus has been divided into two groups on the basis of utilization of ammonium and nitrate salts and the use of citrate as the sole sources of nitrogen and carbon, respectively. This marine organism is most closely related to the nonchromogenic members of the first group, which are able to utilize these compounds. The isolate therefore appears to be a new species for which the name Arthrobacter marinus is proposed because of its original isolation from the marine environment.

The genus Arthrobacter has a propensity for an unusual growth response under conventional methods of culture. They are characterized, and stain Gram-negative 
in the logarithmic phase of growth; however, their cell walls have the chemical composition of Gram-positive cells (Cummings \& Harris, 1959; Gillespie, 1963; Krulwick, Ensign, Tipper \& Strominger, 1967). The change of Gram reaction of $A$. globiformis from Gram-negative in the logarithmic phase of growth to Gram-positive in the late stationary phase is reported to be the result of an alteration in cell wall synthesis during the logarithmic phase of growth (Gillespie, I963).

Wahlin \& Almaden (1939) applied the term 'megalomorph' to those cells which were abnormally long and frequently swollen. The formation of such cells can be induced by a variety of conditions such as magnesium deficiency (Webb, 1949), deficiency in growth factors (Chaplin \& Lochhead, 1956; Chan, 1964), metals (Rosenberg, Renshaw, Van Camp, Hartwick \& Drobnik, I967; Sobek \& Talburt, 1968), antibiotics (Kantor \& Deering, 1968), temperature (Terry, Gaffer \& Sagers, 1966), and pressure (ZoBell \& Cobet, 1962).

The morphological changes observed in Arthrobacter marinus when grown in the presence of $\mathrm{Ni}^{2+}$ appear to involve cell division mechanisms rather than metabolic growth processes. There is a continuation of cellular growth with cessation of multiplication, resulting in enlarged cells. The shape of the bacterial cell is determined by the mechanical rigidity of the cell wall (Salton, 1964). During balanced growth the plasma membrane is in contact with the cell wall and both expand and change shape. The maximum size a cell may attain is determined by the space within the cell wall. The osmotic pressure within the protoplast is at least as high as the surrounding medium so that the cell membrane is pressing against the cell wall with a turgor pressure (Mitchell \& Moyle, 1956). If the cell wall is weakened, its protective action is lost and the protoplast is forced to regulate its own volume unless protected by osmotic support in the medium. Otherwise the cell will burst (Weibull, I953; McQuillen, I960).

An osmotic irregularity is seen to develop in the megalomorph as a result of nickel stress. The cells grown in the absence of nickel are seen to have normal morphology, whereas in the same medium with $4 \times 10^{-4} \mathrm{M}$-nickel the cell wall expands away from the protoplast to produce the appearance of being plasmolysed (P1. 3, fig. I6, I7). Hence the cell appears to have become hypotonic in relation to the exterior environment, resulting in shrinkage of the cell membrane away from the wall. A second possibility is that the cell wall synthesizing system has become uncontrolled with an unregulated production of cell wall material. This may, at the same time, disrupt the relationship between the cell wall and the cytoplasmic membrane needed for cell division. Because of diffusion problems associated with increased size the synthesis of the protoplast may lag behind, with the result that the cell membrane retracts from the wall.

This work was supported in part by grants from the Office of Naval Research, N-000 14-68-C-0269, and the Water Supply and Pollution Control Administration of the Department of the Interior, WP-00650-03. The authors wish to thank Mr Emory Clippert for taking the electron photomicrographs.

\section{REFERENCES}

BARrITt, M. M. (1936). The intensification of the Voges-Proskauer reaction by the addition of $\alpha$ naphthol. Journal of Pathology and Bacteriology 42, 44I-454.

Blankenship, L. C. \& Doetsch, R. N. (I96I). Influence of a bacterial cell extract upon the morphogenesis of Arthrobacter ureafaciens. Journal of Bacteriology 82, 882-888. 
Chan, E. C. S. (1964). Morphological aberration of Arthrobacter globiformis cells due to biotin deficiency. Journal of Bacteriology 87, 64I-65I.

Chaplin, C. E. \& LochHead, A. G. (1956). Abnormal morphology of a bacterium resulting from vitamin $\mathrm{B}_{12}$ deficiency. Canadian Journal of Microbiology 2, 340-342.

ConN, H. J. \& Dimmick, I. (I947). Soil bacteria similar in morphology to Mycobacterium and Corynebacterium. Journal of Bacteriology 54, 29I-303.

Conn, H. J. \& Dimmick, I. (I948). Soil bacteria of the genus Arthrobacter. Soil Science 65, 349-35I.

Conn, H. J., Wolfe, G. E. \& Ford, M. (1940). Taxonomic relationships of Alcaligenes spp. to certain soil saprophytes and plant parasites. Journal of Bacteriology 39, 207-226.

Cowan, S. T. \& STEEL, K. J. (1965). Manual for the Identification of Medical Bacteria. Cambridge University Press.

Cummings, C. S. \& Harris, H. (1959). Taxonomic position of Arthrobacter. Nature, London r84, $83 I-832$.

Dubos, R. \& Miller, B. F. (1937). The production of bacterial enzymes capable of decomposing creatinine. Journal of Biological Chemistry 121, 429-445.

Ensign, J. C. \& RitTenberG, S. C. (I963). A crystalline pigment produced from 2-hydroxypyridine by Arthrobacter crystallopoietes n.sp. Archiv für Mikrobiologie 47, 137-153.

Gasdorf, H. J., Benedict, R. G., Cadmus, M. C., Anderson, R. F. \& Jackson, R. W. (i965). Polymer-producing species of Arthrobacter. Journal of Bacteriology 90, I47-150.

Gillespie, D. C. (1963). Composition of cell wall mucopeptide from Arthrobacter globiformis. Canadian Journal of Microbiology 9, 515-521.

Hugh, R. \& LeIFSON, E. (1953). The taxonomic significance of fermentative versus oxidative metabolism of carbohydrate by various Gram-negative bacteria. Journal of Bacteriology 66, 24-26.

JENSEN, V. (1960). Arthrobacter ramosus sp.nov., a New Arthrobacter Species Isolated from Forest Soils, pp.123-132. Copenhagen, Denmark: Royal Veterinary Agricultural College Yearbook.

JoNES, G. E. (1964). Effect of chelating agents on the growth of Escherichia coli in sea water. Journal of Bacteriology 87, 483-499.

Jones, G. E. (1968). In Marine Biology IV: Unresolved Problems in Marine Biology, p. 449. Edited by C. H. Oppenheimer. New York: Academy of Sciences Interdisciplinary Communications Program.

Kantor, G. J. \& Deering, R. A. (I968). Effect of nalidixic acid and hydroxyurea on division ability of Escherichia coli fil ${ }^{+}$and lon strains. Journal of Bacteriology 95, 520-530.

Krulwick, T. A., Ensign, T. C., Tipper, D. J. \& Strominger, J. L. (1967). Sphere-rod morphogenesis in Arthrobacter crystallopoietes. II. Peptides of the cell wall peptidoglycan. Journal of Bacteriology 94, 74I-750.

Kunn, D. A. \& STARr, M. P. (1960). Arthrobacter atrocyaneus n.sp. and its blue pigment. Archiv für Mikrobiologie 36, 175-181.

LochHEAD, A. G. (1957). Arthrobacter. In Bergey's Manual of Determinative Bacteriology, pp. 605612. Edited by R. S. Breed, E. G. D. Murray and N. R. Smith. Baltimore: Williams \& Wilkins.

LOCHHEAD, A. G. (1958). Two new species of Arthrobacter requiring respectively vitamin $\mathbf{B}_{12}$ and the terregens factor. Archiv für Mikrobiologie 31, 163-170.

Lyman, J. \& Fleming, R. H. (1940). Composition of sea water. Journal of Marine Research 3, I $34-146$.

Manual of Microbiological Methods (1957). Society of American Bacteriologists. New York: McGraw-Hill.

Marmur, J. (I96I). A procedure for the isolation of deoxyribonucleic acid from micro-organisms. Journal of Molecular Biology 3, 208-2 18.

Marmur, J., Falkow, S. \& Mandel, M. (1963). New approaches to bacterial taxonomy. Annual Review of Microbiology $\mathbf{7}, 329-372$.

MCQuillen, K. (1960). Bacterial protoplasts. In The Bacteria. Vol. I. Structure, pp. 249-359. Edited by I. C. Gonsalus and R. Y. Stanier. New York: Academic Press.

Mitchell, P. \& Moyle, J. (1956). Osmotic function and structure in bacteria. In Bacterial Anatomy. Sixth Symposium of the Society for General Microbiology, pp. 150-180. Edited by E. T. C. Spooner and B. A. D. Stocker. Cambridge University Press.

OpPenheimer, C. \& ZOBELL, C. E. (1952). The growth and viability of sixty-three species of marine bacteria as influenced by hydrostatic pressure. Journal of Marine Research rr, IO-I 8.

Pringsheim, E. G. (I964). Pure Cultures of Algae, pp. 40-43. New York: Hafner Publishing Co. 
Rosenberg, B., Renshaw, E., Van Camp, L., Hartwick, J. \& Drobnik, J. (I967). Platinuminduced filamentous growth in Escherichia coli. Journal of Bacteriology 93, 716-721.

Salton, M. R. J. (1964). The Bacterial Cell Wall, pp. 8-9. New York: Elsevier Publishing Co.

SCARPINO, P. V. \& Pramer, D. (1962). Evaluation of factors affecting the survival of Escherichia coli in sea water. VI. Cysteine. Applied Microbiology 1o, 436-440.

Schildkraut, C. L., Marmur, J. \& Doty, P. (1962). Determination of the base composition of deoxyribonucleic acid from its buoyant density in $\mathrm{CsCl}$. Journal of Molecular Biology 4, 430-443.

Schippers-Lammertse, A. F., Muijsers, A. O. \& Klatser-Oedekerk, K. B. (1963). Arthrobacter polychromogenes nov.spec., its pigments and a bacteriophage of this species. Antonie van Leeuwenhoek 29, I-15.

SGuros, P. L. (1955). Microbial transformations of the tobacco alkaloids. I. Cultural and morphological characteristics of a nicotinophile. Journal of Bacteriology 69, 28-37.

SKERMAN, V. B. D. (1967). Guide to the Identification of the Genera of Bacteria, 2nd edn. Baltimore: Williams \& Wilkins.

Sobeck, J. M. \& TALBURT, D. E. (I968). Effects of the rare earth cerium on Escherichia coli. Journal of Bacteriology 95, 47-51.

StARR, M. P. \& KUHN, D. A. (1962). On the origin of V-forms in Arthrobacter atrocyaneus. Archiv für Mikrobiologie 42, 289-298.

TERRY, D. R., GAFFer, A. \& SAGERS, R. D. (I966). Filament formation in Clostridium acidiurici under conditions of elevated temperatures. Journal of Bacteriology 9r, I625-I634.

Wahlin, J. G. \& Almaden, P. J. (I939). Megalomorphic phase of bacteria. Journal of Infectious Diseases 65, I47-155.

WANG, SHIH YI \& HASHAGEN, J. M. (1964). The determination of the base composition of deoxyribonucleic acids by bromination. Journal of Molecular Biology 8, 333-340.

WEBB, M. (1949). The influence of magnesium on cell division. II. The effect of magnesium on the growth and cell division of various bacterial species in complex media. Journal of General Microbiology 3, 410-417.

WeIBUll, C. (1953). The isolation of protoplasts from Bacillus megaterium by controlled treatment with lysozyme. Journal of Bacteriology 66, 688-695.

WIRSEN, C. (1966). The Effect of Nickel on Marine Bacteria. Master's Thesis, Boston University.

ZoBell, C. E. \& COBET, A. B. (I962). Growth, reproduction and death rates of Escherichia coli at increased hydrostatic pressures. Journal of Bacteriology 84, 1228-1236.

ZoBell, C. E. \& UPHAM, H. C. (1944). A list of marine bacteria including descriptions of sixty new species. Bulletin of the Scripps Institution of Oceanography 5, 239-292.

\section{EXPLANATION OF PLATES}

\section{Plate I}

Cellular development of normal cells of Arthrobacter marinus in the basal medium at $25^{\circ}$. Photomicrographs by phase contrast. $\times 2500$.

Fig. I. Inoculum, $18 \mathrm{~h}$. culture from surface of slant of marine agar medium 2216.

Fig. 2. Logarithmic phase, 5 h. after inoculation.

Fig. 3. Late stationary phase, 8 days after inoculation.

Fig. 4 and 5. Electron micrograph of flagellum. Cells taken $12 \mathrm{~h}$. after inoculation and shadow cast with tungstic oxide at an angle of 30 degrees and $24 \AA$ thick. $\times 10,000$.

\section{Plate 2}

Morphology of cells grown in the presence of increasing concentrations of nickel added to the basal medium. Cultures were incubated at $300 \mathrm{rev} . / \mathrm{min}$. at $25^{\circ}$. Photomicrographs by phase contrast. $\times 2500$.

Fig. 6. Inoculum, $18 \mathrm{~h}$. culture from surface of slant of marine agar medium 2216.

Fig. 7. Culture after $24 \mathrm{~h}$. incubation in $\mathrm{I} \times 10^{-4} \mathrm{M}$-nickel. 
Journal of General Microbiology, Vol. 62, No. 2

Plate I
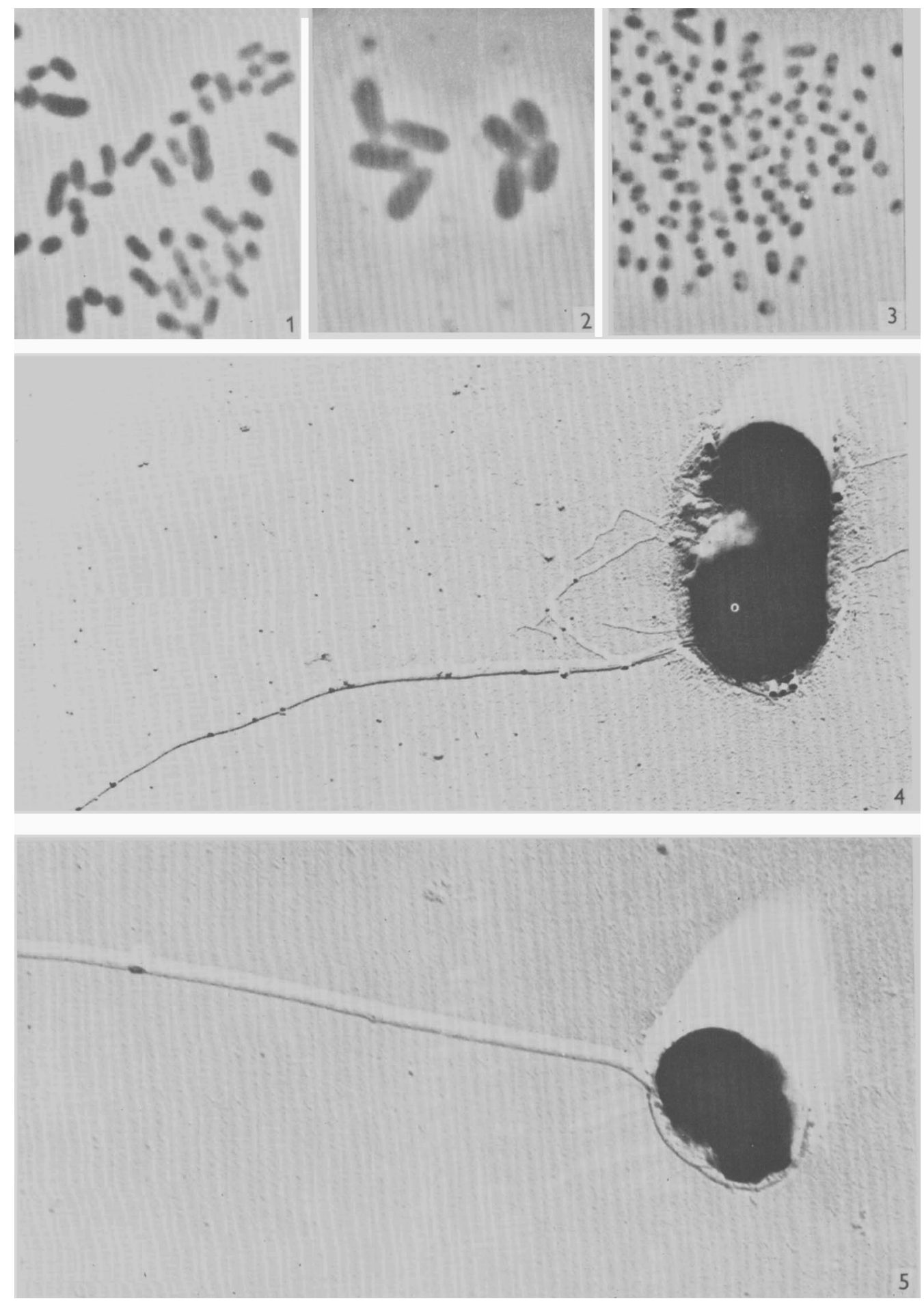

A. B. COBET, C. WIRSEN, JUN. AND G. E. JONES

(Facing p. I68) 
Journal of General Microbiology, Vol. 62, No. 2

Plate 2
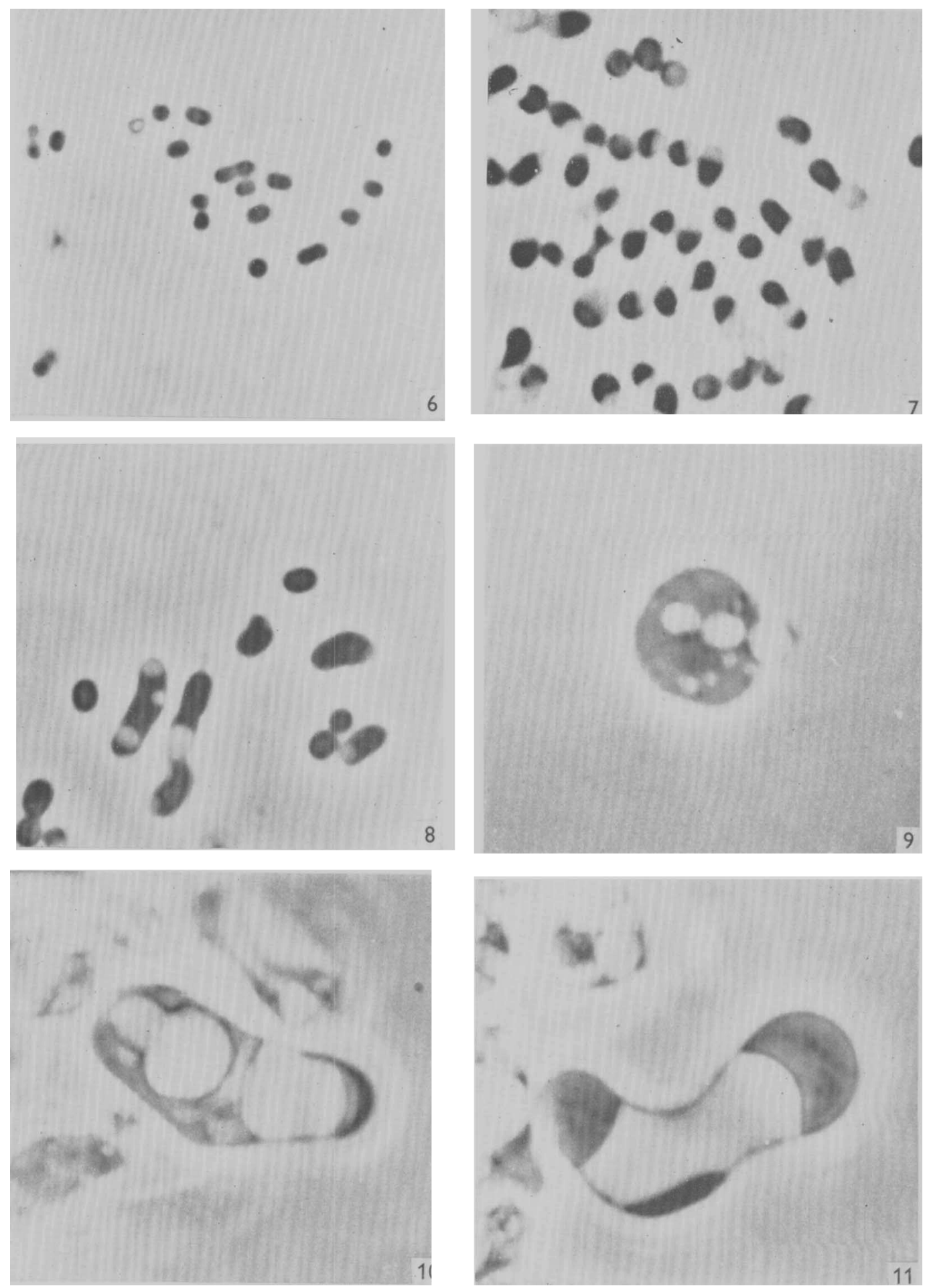

A. B. COBET, C. WIRSEN, JUN. AND G. E. JONES 
Journal of General Microbiology, Vol. 62, No. 2

Plate 3
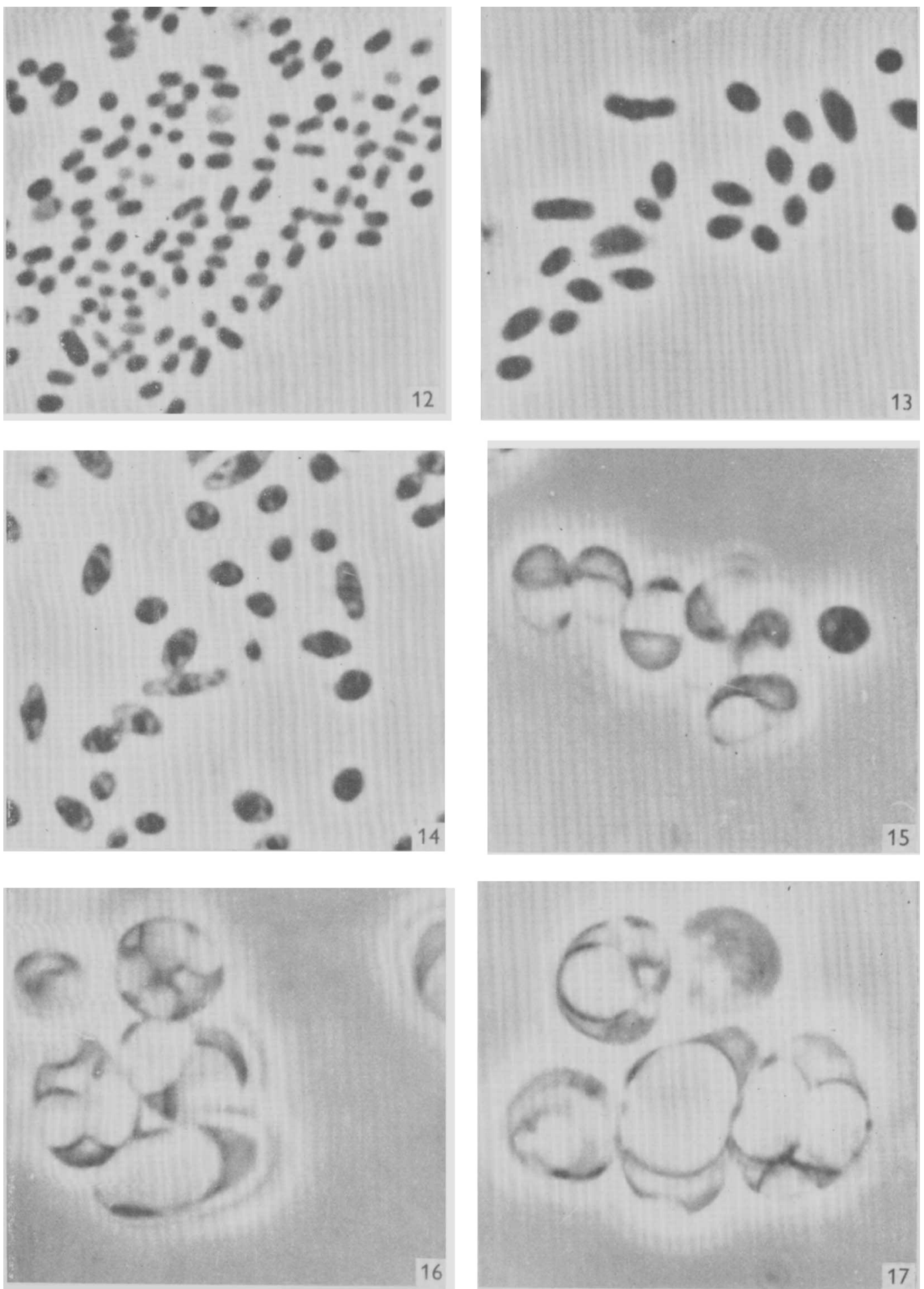

A. B. COBET, C. WIRSEN, JUN. AND G. E. JONES 
Fig. 8. Culture after $30 \mathrm{~h}$. incubation in $2 \times 10^{-4} \mathrm{M}$-nickel.

Fig. 9. Culture after $96 \mathrm{~h}$. incubation in $3 \times 10^{-4} \mathrm{M}$-nickel.

Fig. 10 and II. Culture after $120 \mathrm{~h}$. incubation in $4 \times 10^{-4} \mathrm{M}$-nickel.

Plate 3

Morphological changes of a culture grown at $25^{\circ}$ in basal medium containing $4 \times 10^{-4} \mathrm{M}$-nickel. Wet mounts prepared at times shown and photomicrographs made by phase contrast. $\times 2500$.

Fig. I2. Inoculum, $18 \mathrm{~h}$. culture from slant of marine agar medium 2216.

Fig. 13. After $1 \cdot 5 \mathrm{~h}$. incubation.

Fig. I4. After $2 \cdot 5 \mathrm{~h}$. incubation.

Fig. I5. After $4.5 \mathrm{~h}$. incubation.

Fig. I6. After 6.5 h. incubation.

Fig. 17. After Io h. incubation. 